\title{
Algılanan Örgütsel Destek ve Duygusal Bağlılık Arasındaki İlişkinin İncelenmesi: Mersin İlinde Banka Çalışanları Üzerinde Bir Araştırma (Investigation of the Relationship Between Perceived Organizational Support and Affective Commitment: A Research on Bank Employees in Mersin Province)
}

\section{Ferah KEKLİK OKUL (iD) a}

a Mersin, Türkiye. ferah.keklik06@gmail.com

\begin{tabular}{l} 
MAKALE BİLGİsi \\
\hline Anahtar Kelimeler: \\
Algılanan Örgütse \\
Destek \\
Duygusal Bağlllık \\
Banka Sektörü \\
Gönderilme Tarihi 27 \\
Ekim 2020 \\
Revizyon Tarihi 12 \\
Şubat 2021 \\
Kabul Tarihi 14 Mart \\
2021
\end{tabular}

Makale Kategorisi: Araştırma Makalesi

\section{ÖZET}

Amaç - Bu araştırmanın amacı, algılanan örgütsel destek ve duygusal bağlılı̆̆ın demografik faktörlere göre farklılıklarını incelemek ve algılanan örgütsel destek ile duygusal bağlılık arasındaki ilişkiyi tespit etmektir.

Yöntem: Araştırmada nicel araştırma yöntemlerinden bağıntısal ve nedensel karşılaştırma yöntemleri kullanılmıştır. Araştırmanın evrenini, Mersin ilindeki banka çalışanları oluşturmaktadır. Araştırma verileri 2019 yılında, 19 banka şubesinde çalışanlardan anket formu kullanılarak kolayda örnekleme yöntemi ile elde edilmiştir (n=344). Araştırmada, Eisenberger vd. (1986) tarafından geliştirilen ve Akkoç vd. (2012) tarafından Türkçe'ye uyarlanan "Algılanan Örgütsel Destek Ölçeği" ile Meyer ve Allen (2001) tarafından geliştirilen ve Wasti (2000) tarafından Türkçe'ye uyarlanan "Örgütsel Bağlllık Ölçeği”nin duygusal bağlllık boyutu kullanılmıştır. Veriler SPSS 23 istatistik paket programı ile tanımlayıcı istatistikler, bağımsız gruplarda t testi, tek yönlü varyans analizi, regresyon analizi ve korelasyon analizi yapılarak incelenmiştir.

Bulgular - Araştırma sonucunda, algılanan örgütsel desteğin medeni durum, yaş, eğitim durumu ve gelire göre duygusal bağllı̆̆ğn ise medeni durum, yaş ve eğitim durumuna göre farklılaştığı tespit edilmiştir. Korelasyon ve regresyon analizleri sonucunda duygusal bağlllık ile algılanan örgütsel destek arasında pozitif yönlü ilişki olduğu ve duygusal bağlılı̆̆ın \%23 oranında algılanan örgütsel destek tarafından açılandığı bulgulanmıştır.

Tartışma - Örgütsel bağllık ve alt boyutları ile algılanan örgütsel desteğin birey ve örgüt düzeyindeki davranış değişkenleriyle ilişkili olduğu çok sayıda araştırma tarafından desteklenmektedir. Duygusal bağlılık ile algılanan örgütsel destek kavramları algıya dayanan, bireye özgü, düşünsel ve duygusal boyutta oluşan kavramlardır. Bu nedenle yapılan çalışmaların bireysel ve örgüt ortamdaki öncülleri ile farklı örgüt ortamlarında tekrarlanmasının alanyazına ve uygulayıcılara katkıda bulunacağı öngörülmektedir.

\begin{tabular}{|c|c|}
\hline ARTICLE INFO & ABSTRACT \\
\hline $\begin{array}{l}\text { Keywords: } \\
\text { Perceived } \\
\text { Organizational Support }\end{array}$ & $\begin{array}{l}\text { Purpose - The purpose of this study is to examine the differences in perceived organizational support and } \\
\text { affectice commitment according to demografic factors and to determine the relationship between perceived } \\
\text { organizational support and affective commitment. }\end{array}$ \\
\hline $\begin{array}{l}\text { Affective Commitment } \\
\text { Banking Sector. }\end{array}$ & $\begin{array}{l}\text { Design/methodology/approach - In this study, among the quantitative research methods, relational and } \\
\text { causal comparison methods were used. The population of the study is consists of bank employees in Mersin. } \\
\text { The research data were obtained from employees employed in } 19 \text { banks branches in 2019, using a } \\
\text { questionnaire form, using convenience sampling method ( } n=344) \text {. In the study, "Perceived Organizational }\end{array}$ \\
\hline $\begin{array}{l}\text { Received } 27 \text { October } \\
2020 \\
\text { Revised } 12 \text { February } \\
2021 \\
\text { Accepted } 14 \text { March } 2021\end{array}$ & $\begin{array}{l}\text { Support Scale" developed by Eisenberger et al. (1986) and adapted into Turkish by Akkoç et al. (2012) and } \\
\text { affective commitment dimension of the "Organizational Commitment Scale" developed by Meyer and Allen } \\
\text { (2001) and adapted into Turkish by Wasti (2000) were used. The data were analyzed by using descriptive } \\
\text { statistics, independent groups t test, one way analysis of variance, regression analysis and correlation analysis } \\
\text { with SPSS } 23 \text { statistical package program. }\end{array}$ \\
\hline \multirow[t]{2}{*}{$\begin{array}{l}\text { Article Classification: } \\
\text { Research Article }\end{array}$} & $\begin{array}{l}\text { Findings - As a result of research, it was determined that perceived organizational support differs according } \\
\text { to marital status, age, educational status and monthly income, and affective commitment according to marital } \\
\text { status, age and educational status. As a result of the correlation and regression analysis, it was found that } \\
\text { there was a positive relationship between affective commitment and perceived organizational support, and } \\
\text { affective commitment is explained by perceived organizational support at a rate of } 23 \% \text {. }\end{array}$ \\
\hline & $\begin{array}{l}\text { Discussion - It is supported by numerous studies that organizational commitment and its sub-dimensions } \\
\text { and percevied organizational support are related to behavior variables at individual and organizational levels. } \\
\text { The concepts of perceived organizational support and affective commitment to the organization are based on } \\
\text { perception individual, intellectual and emotional. Therefore, it is predicted that the repetition of the studies } \\
\text { in this field in individual and organizational environments and in different organizational environments will } \\
\text { contribute to the literature and practitioners. }\end{array}$ \\
\hline
\end{tabular}

\section{Önerilen Atıf/Suggested Citation}

Keklik Okul, F. (2021). Algılanan Örgütsel Destek ve Duygusal Bağlılık Arasındaki İlişkinin İncelenmesi: Mersin İlinde Banka Çalışanları Üzerinde Bir Araştırma, İşletme Araştırmaları Dergisi, 13 (1), 464-4. 


\section{GİRISs}

Rekabetin gün geçtikçe arttığı ve daha karmaşık bir hale dönüştüğü günümüzde küreselleşme, artan rekabet, pazar dinamikleri ve teknolojideki gelişmeler ile birlikte hızla değişen koşullara ayak uydurabilmek bir zorunluluk haline gelmiştir ve buna bağlı olarak örgütlerde "insan" unsurunun önemi ve değeri gün geçtikçe artmaktadır. Örgütlerin amaçlarına ulaşmasında ve varlığını devam ettirebilmesinde insan faktörü ana unsur olarak görülmektedir. Günümüz iş yaşamında örgütler, biçimsel iş gereklerinin de ötesinde örgütün amaç ve hedeflerine bağlı ve performanslarına katkıda bulunan işgörenlere daha çok bağımlı hale gelmiştir (Gürbüz, 2000: 49; Özdevecioğlu, 2003: 114). Bu bağlamda örgütsel bağlılık, örgütler için hayati öneme sahip olmakla birlikte örgütlerin sürekliliklerini sağlama çabalarının temel etkinliklerinden ve nihai hedeflerinden biri olarak görülmektedir (Balay, 2000: 3). Örgütsel bağlılık alan yazınındaki en etkili yaklaşım, örgütsel bağlllı̆ı̆n en kuvvetli bağlanma biçimi olan duygusal açıdan ele alınmasıdır (Mowday, 1998: 390). Duygusal bağl1lık, işgörenlerin örgüt üyeliğinden memnun olmalarını sağlayan, örgütte bulunduğu sürece maddi veya manevi herhangi bir zorunluluk hissetmeden örgüte bağlı olan, bireysel ve örgütsel değerler arasındaki uzlaşmadan kaynaklanan aktif bir şekilde örgüte bağlanma biçimidir.

Algılanan örgütsel destek, işgörenin çalıştı̆̆ örgütün kendisine değer verdiği, düşüncelerini önemsediği ve kendisine sağlanacak faydaların örgüt tarafından göz önünde bulundurulduğuna dair inanç ve algı olarak tanımlanmaktadır (Eisenberger vd., 2002: 565). Örgütsel destek teorisyenlerine göre, örgütsel desteğin ileri düzeyde olması, çalışanlarda etkili iş davranışlarını ortaya çıkarmaktadır (Eisenberger vd. 1987: 181). Örgütsel davranış alan yazınında yapılan çalışmalarda ise algılanan örgütsel desteğin en önemli sonuçlarından birinin duygusal bağlılık olduğu belirtilmektedir. Shore ve Wayne (1993: 776) örgütsel destek algısının artması ile işgörenlerde ileri düzeyde örgüte karşı duygusal bağlllık görüldüğünü belirtmişlerdir. Edwards ve Peccei (2010: 7) ise kendilerinin örgüt tarafından desteklenip değerli olduğunu hisseden çalışanların; örgütlerine karşı daha kuvvetli bir şekilde duygusal bağlllık geliştirdiklerini belirtmişlerdir.

Algılanan örgütsel desteğin örgütsel adalet, yöneticinin çalışanlarına sağladığı destek gibi daha çok sosyoduygusal yönleriyle ilişkili olan duygusal bağlılığın, işgörenlerin örgüt içerisinde duygusal açıdan desteklendikleri ve örgüte yaptıkları katkıların takdir edilmesi durumunda artması mümkündür. Bununla birlikte algılanan örgütsel destek algısı işgörenlerin değer duyguları ile yeterlilik inançlarını da pozitif yönde etkilemektedir. Ayrıca örgüt ve çalışan arasındaki karşılıklılık ilkesine bağlı olarak mutlu olan çalışanlar, örgütlerinde çalışmaya devam etmeyi tercih etmektedirler (Tamer ve Bozayküt Bük, 2020: 143). Örgütün işgörene bağlllığının bir göstergesi olan örgütsel destek, işgören için de örgütünü önemseme, örgüte bağlllık ve sadakatle karşıllı verme yükümlülüğü oluşturmaktadır.

Alanyazında algılanan örgütsel destek ve örgütsel bağlılık arasındaki ilişkilerin farklı örgütlerde incelendiği görülmektedir. Bu araştırma kapsamında hizmet sektöründe bulunan bankalarda algılanan örgütsel destek ve örgütler açısından en güçlü bağlllık türü olan duygusal bağlılık arasındaki ilişkilerin araştırılması amaçlanmıştır. Bu amaçla yapılan çalışmada banka işgörenlerinin örgütsel destek algıları ve duygusal bağlılıkları demografik faktörlere göre farklılaşmakta mıdır? Algılanan örgütsel desteğin duygusal bağlılıkla ilişkisi var mıdır? Algılanan örgütsel destek duygusal bağllı̆̆g etkilemekte midir? Şeklinde oluşturulan tüm sorular nicel araştırma yöntemi çerçevesinde incelenmiştir. Araştırma kapsamında banka sektörü işgörenlerinin örgütsel destek algısı ve duygusal bağlılık düzeylerinin belirlenmesi, örgütsel destek algısı ve duygusal bağlılığın demografik değişkenler açısından farklılıklarının incelenmesi ile örgütsel destek algısı ve duygusal bağlılık arasındaki ilişkiyi tespit etmek amaçlanmıştır. Örgütsel yaşamın daha iyi anlaşılması ve insan faktörünün örgüt yönetimine pek çok konuda yardımcı olmasını sağlayabilmek için bu alanda yapılan çalışmaların alan yazına ve örgütlere katkıda bulunacağı düşünülmektedir.

\section{KAVRAMSAL ÇERÇEVE}

\subsection{Algılanan Örgütsel Destek}

Örgütlerin işgörenlerine karşı ne kadar ilgili olduğuyla ve verdiği değerle ilgili algı temelli bir kavram olan algılanan örgütsel destek bireye özgü olarak düşünsel ve duygusal boyutta oluşmaktadır (Allen vd., 2008: 557; Bozkurt, 2007: 150). Örgütün işgörenlerine uyguladığı belirli stratejiler ya da tutum ve davranışlar karşısında, bireylerde oluşan soyut bir kavramdır. Algılanan örgütsel destek, işgörenin çalıştığı örgütün kendisine değer verdiği, düşüncelerini önemsediği ve kendisine sağlanacak faydaların örgüt tarafından göz önünde bulundurulduğuna dair inanç ve algı olarak tanımlanmaktadır (Eisenberger vd., 2002: 565; Kambu vd., 2012: 32). Algılanan örgütsel destek kavramı bireyler arasında, birey ile grup arasında veya gruplar 


\section{F. Keklik Okul 13/1 (2021) 464-480}

arasında oluşan sosyal bir etkileşim süreci olarak tanımlamaktadır. İşgörenlerin örgüt ortamında kendilerini destekleyen bir örgütün varlığını hissetmeleri ve güvende olduklarını algılamalarıdır. Örgütün kendilerine destek verdiğini algılayan işgörenler, işlerine daha sıkı bir şekilde bağlanıp örgütten ayrılmayı düşünmeyeceklerdir (Özdevecioğlu 2003: 116). Bu nedenle işgörenlerin örgütsel destek algısı onların örgütlerine olan bağlllıklarını da önemli derecede etkilemektedir (Moorman vd., 1998: 352). Algılanan örgütsel desteğin yüksek olduğu örgütlerde işgörenler örgütsel amaçlara ulaşmak için daha fazla çaba gösterdiklerinde ödüllendirilmeyi beklemektedir ve aynı zamanda çalıştıkları örgütle olumlu bir ilişki ve bağ kurmaktadır. Örgütsel destek çalışanlar tarafından algılandığında övgü ve takdir ihtiyacını da karşılamaktadır (Silbert, 2005: 7). Algilanan örgütsel desteğin ileri düzeyde olduğu örgütlerde örgütsel amaçlara ulaşmak için işgörenler daha özverili çalışmaktadırlar ve performanslarında da önemli ölçüde artış görülmektedir. Bu olumlu sonuçların ortaya çıkmasında ve işgörenlerin örgüte yönelik pozitif yönde duygu ve düşüncelere sahip olmasında üst düzeydeki yetkililer önemli rol oynamaktadır. Yöneticilerin çalışanların örgüte katkılarını önemseyip onları takdir etmesi çalışanlar tarafından örgüt politikası olarak görülmektedir. Yöneticiler astlarının yaptıkları işi değerlendirmede ve onlara yön vermede kritik öneme sahiplerdir ve buna bağlı olarak çalışanlar tarafından örgütün temsilcisi ve somut bir yansıması olarak görülmektedirler (Eisenberger vd., 1986: 501; Silbert, 2005: 7).

Özdevecioğlu'na (2003) göre işgörenlerinin iyiliğini ve mutluluğunu göz önünde bulunduran, destekleyen bir örgütte olması gereken nitelikler aşağıda sıralanmıştır:

1. İşgörenlerinin yaratıcı ve yenilikçi düşüncelerini, önerilerini ve eleştirilerini önemsemek ve bunları uygulamaya aktararak, çalışanlar tarafından yapılan öneri ve eleştiriler çerçevesinde işletmede değişiklikler yapmak,

2. İşgörenlerinin başarılı olmaları durumunda örgütte sürekli çalışabileceklerine ilişkin güvence vermek ve onlara iş güvenliği sağlamak,

3. Örgüt içinde bütün kademeler arasındaki ilişkilerin olumlu yönde gelişmesini sağlayarak iletişimi yüksek seviyede tutmak,

4. Çalışma ortamında, tüm işgörenlere eşit muamele ve uygulamalarda bulunmak, adam kayırmacılık yapmamak, haksız taraf tutmamak, herkese adaletli davranmak,

5. İşgörenlerin önemsendiğinin hissettirilmesi, karar alınırken onları da göz önünde bulundurmak, işgörenleri takdir etmek, başarılarını övmek ve ödüllendirmek ile örgütler, çalışanlarının gözünde destekleyici örgüt algisının oluşmasına neden olacaktır (Özdevecioğlu, 2003: 115-117).

Örgütsel davranış alanında yapılan araştırmalar, algılanan örgütsel desteğin işe adanmışlık, iş tatmini, örgütsel bağlllık, işe angaje olma, işe bağllık, performans, işe uyum ve genel uyum ile pozitif yönde; işten ayrılma niyeti, iş gerginliğii, işten kaytarma, işe devamsızlık ve işgücü devir oranıyla negatif yönde ilişkili olduğunu göstermektedir (Eisenberger vd., 1990: 51; Chen vd., 2005; Takeuchi vd., 2009; Beckers vd., 2004: 1282; Aykan, 2007: 126).

\section{2. Örgütsel Bağlılık}

Meyer ve Allen (1997) örgütsel bağlllı̆̆ı, işgören ve örgüt arasındaki ilişkiyle oluşan ve işgörenin örgütte çalışmaya devam etmesi konusunda karar vermesini sağlayan, psikolojik boyutlu bir davranış olarak ifade etmektedirler. İşgörenin örgütün üyesi olarak kalma yolunda ileri derecede istek duyması, örgüte güçlü bir inançla bağlı kalarak örgütü için ileri düzeyde gayret göstermesi, örgütün bütün faaliyetleri, menfaatleri ve başarısı ile kimlik birliği oluşturmaktır (İbicioğlu, 2000: 13 ). Bu bağlamda örgütsel bağlılık, kişinin çalıştığ1 örgütle oluşturduğu kimlik ortaklığını, kendini örgütün bir parçası olarak algılamasının ve örgütle farklı yönlerden özdeşleşmesinin derecesi olarak ifade edilmektedir (İmamoğlu, 2016: 45). Örgütsel bağlllık, üç önemli unsurla şekillenmektedir (Eisenberg vd., 1987: 181). Bunlar:

- Çalışanların örgütün amaç ve değerlerine karşı güçlü bir şekilde inanç duyması,

- Örgüt için anlamlı bir şekilde çalışmaya istekli olma ve

- Örgüt üyeliğinin devam ettirilmesi için güçlü bir şekilde istek duymadır.

Bu bağlamda örgütsel bağlılık, işgörenlerin örgütün başarısı için gösterdiği ilgi, örgüte karşı hissettiği inanç, örgüte karşı duyduğu sadakat ve örgüte bağlanma biçimidir (Doğan ve Kılıç, 2008: 39). Bu alanda yürütülen çalışmalar örgüte karşı duyulan bağlılığın; kişisel faktörler ile örgütün değerleri, örgütteki adalet olgusu, örgüt 


\section{F. Keklik Okul 13/1 (2021) 464-480}

kültürü, örgüt içi iletişim, üst yönetimin işgörenlere yaklaşım tarzı, liderlik davranışları, iş dizaynı, iş yoğunluğu, ödül ve ücret gibi örgütsel faktörler ile belirlendiğini göstermektedir (Hoş ve Oksay, 2015: 7; Doğan ve Kılıç, 2008: 40).

Meyer ve Allen (1991) örgütsel bağllı̆̆ı oluşturan unsurları "Duygusal Bağlılık", "Devamlılık Bağlılığı" ve “Normatif Bağlılık" olarak 3 boyutta incelemişlerdir (Meyer ve Allen, 1991: 63). Devamlılık bağlılığı (zorunlu bağlılık), örgütte kalmanın çalışan tarafından algılanan ekonomik değerinin olması nedeniyle çalışanın örgütte kalmayı zorunlu olarak sürdürmesini ifade etmektedir. Çalışan örgütten ayrılacağı takdirde karşılaşacağı maliyetleri dikkate alarak örgüte bağlılık hissetmektedir. Normatif bağlılık (minnet bağlılı̆̆1), çalışanın ahlaki veya etik nedenlerden dolayı örgütte çalışmayı sürdürmeyi bir görev ve sorumluluk olarak görmesi ve bu nedenle örgütte kalma zorunluluğunu hissetmesidir (Demirkol, 2014: 4). Duygusal bağlılık ise, çalışanın örgütüyle duygusal bağlantısını, örgütün değerlerine olan inancını, buna bağlı olarak örgütle özdeşleşmesini ifade etmektedir (Robbins ve Judge, 2013: 77). Kurumsal değerleri, kuralları kabullenme ve örgütte kalmayı sürdürmeye karşı içten duyulan bir inanç olarak görülmektedir. Bu bağlamda duygusal bağlılık devamlılık ve normatif bağlılıkta olduğu gibi dış faktörlerden kaynaklanan bir bağlılık değil güdü, dürtü gibi içsel faktörlerden kaynaklanan, kendiliğinden ortaya çıkan bağlllıktır (Tutar, 2007: 106).

\subsection{Duygusal Bağlılık Kavramı}

Örgütsel bağlılık alanyazınındaki en etkili yaklaşım, örgütsel bağlılığın duygusal açıdan ele alınmasıdır (Mowday, 1998: 390). Allen ve Meyer (1990: 3)'a göre çalışanın örgüte duygusal açıdan yakınlık hissedip örgütsel objelere sarılması ve örgütüyle özdeşleşmesi duygusal bağlllık olarak tanımlanmaktadır. Duygusal bağl1lık, çalışanın kendisinin ve örgütünün amaç ve değerlerini içselleştirip, özdeşleştirerek başarıya ulaşmasını, örgütün menfaati için ileri derecede görevini yerine getirme çabasını ve aynı zamanda güçlü bir şekilde örgütte kalma isteğini ifade etmektedir. Çalışanların örgüte duygusal yönden bağlanması ve bağlı oldukları örgüt üyeliğinden hoşnut olmaları, kişiye ve örgüte ait değerler arasındaki uzlaşıdan kaynaklanan bağlanma biçimidir (Wiener, 1982: 423-424). Bu bağlamda duygusal bağlllık örgütün vizyon ve misyonun paylaşılması, örgütteki kurallara karşı gösterilen saygı ile oluşan bağlılıktır (Tutar, 2007: 106). Bu açıdan bakıldığında duygusal bağlılık, çalışanların örgüte karşı pasif bir şekilde bağlanmalarını ve zorunlu olarak itaat etmelerini değil, örgütün daha başarılı olabilmesine katkıda bulunarak fedakârlıklar yapmaya gönüllü olmalarını sağlayan aktif bir bağlanmadır (Gürbüz, 2006: 50). Örgüte duygusal yönden bağlı çalışanlar için örgüt büyük bir öneme sahiptir ve örgütte kariyerlerini devam ettirme konusunda isteklidirler. Çalışanların duygusal açıdan örgüte güçlü bir bağ ile bağlanmaları, çalışan ile örgüt uyumundan ve aynı zamanda kişinin örgüt kimliği ile özdeşleşmesinden kaynaklanmaktadır (Çekmecelioğlu, 2006: 299). Mathieu ve Zajac'a (1990) göre duygusal bağlllık örgüt ile çalışan arasındaki entegrasyonun önemli bir göstergesidir. Duygusal bağlllık, örgütler için en çok arzu edilen ve çalışanlarına en fazla aşılamak istenilen bağlanma şeklidir (Porter, Steers ve Boulian 1973: 604). Bunun en önemli nedeni; çalışanların kendilerini örgütün bir paydaşı olarak görmeleri, örgüte sadık kalmaları ve bu motivasyonel eğilimle de örgüt için istenilenden daha fazla gayret göstermeleri, örgüte karşı maddi ve manevi herhangi bir zorunluluk, otorite ya da baskı hissetmeden örgüte duydukları inanç ve sempati ile bağ kurmalarıdır (Karasandık, 2013: 38-39). Duygusal bağlılığın arttırılması; örgütte alınan kararlara katılımda bulunma, örgüt içinde güven ortamının oluşturulması, çalışanlar arasında eşitliğin sağlanması ve çalışanların önemsenmesi; bilgi paylaşımı ve bunu destekleyen bir örgüt kültürünün varlığı ile mümkündür (Doğan ve Kılıç, 2008: 39-42).

\subsection{Algılanan Örgütsel Destek ve Duygusal bağlılık Arasındaki İlişki}

Özakar (2019) örgütsel bağlllık, örgütsel destek ve psikolojik güçlendirme arasındaki ilişkileri incelemek amacıyla yaptığı çalışmada, örgütsel desteğin örgütsel bağllılı ile alt boyutları üzerinde etkisi olduğunu bulgulamıştır. Ayrıca çalışmada psikolojik güçlendirme ve alt boyutlarının da örgüte bağlılık üzerinde pozitif yönlü etkisi olduğunu tespit etmiştir.

Kim vd., (2016) tarafından yapılan çalışmada örgütsel yeterlilik, algılanan örgütsel destek ile duygusal bağlılık arasındaki ilişkiler incelenmiştir. Çalışma sonucunda algılanan örgütsel destek ve duygusal bağlılık arasında, duygusal bağlılık ile rol performansı ve ekstra rol performansı arasında pozitif yönlü ilişkiler olduğu bulgulanmıştır. Bununla birlikte çalışma sonucunda algılanan örgütsel yeterliliğin bu ilişkiler arasında düzenleyici etkiye sahip olduğu tespit edilmiştir. 


\section{F. Keklik Okul 13/1 (2021) 464-480}

Marique vd. (2012) örgütsel özdeşleşme, örgütsel destek algısı ve duygusal bağlılık arasındaki ilişkileri tespit etmek için yaptıkları çalışmada, örgütsel destek algısı ve duygusal bağlılık arasında pozitif yönlü bir ilişki olduğunu ve örgütsel özdeşleşmenin bu ilişkide düzenleyici etkisi olduğunu tespit etmişlerdir.

Kaplan (2010) yaptığı çalışmada örgütsel destek algısı ile normatif ve duygusal bağlılık arasında pozitif yönlü ilişki, devamlılık bağlılığı arasında ters yönlü ilişki olduğunu tespit etmiştir. Araştırma bulguları Özdevecioğlu (2003) tarafından yapılan araştırma sonuçları ile benzerlik göstermektedir. Özdevecioğlu (2003) ise yaptığı çalışma sonucunda algılanan örgütsel destek arttıkça çalışanların örgütsel bağlılıkları ve alt boyutları olan duygusal bağlılıkları, normatif bağlılıkları ve devamlılık bağllıklarının da arttı̆̆ı bulgulanmıştır.

Rhoadaes ve diğerleri (2001) duygusal bağlllık ile örgütsel destek arasındaki ilişkiyi incelemek, örgütsel ödüllendirmeler, prosedürel adalet, yönetici desteği ve duygusal bağlllık arasındaki ilişkiyi incelemek ve algılanan örgütsel desteğin aracı rolünü belirlemek amacıyla Amerika'da üniversite mezunları ile yaptıkları çalışmada algılanan örgütsel desteğin duygusal bağlılık ile anlamlı bir ilişkisi olduğunu ve algılanan örgütsel desteğin diğer değişkenler ile arasındaki ilişkide aracılık rolü olduğunu bulgulamışlardır.

\section{YÖNTEM}

\subsection{Araştırmanın Modeli}

Banka işgörenlerinin algılanan örgütsel destek ve duygusal bağlllıkları arasındaki ilişkiyi test etmek ve işgörenlerin demografik özelliklerine göre algılanan örgütsel destek ve duygusal bağlllıklarının farklılık gösterip göstermediğini incelemek amacıyla oluşturulan 12 temel hipotez aşağıda yer almaktadır.

H1: İşörenlerin algılanan örgütsel destekleri cinsiyetlerine göre farklılık göstermektedir.

$\mathbf{H}_{2}$ : İşgörenlerin duygusal bağll1ıkları cinsiyetlerine göre farklılık göstermektedir.

$\mathbf{H}_{3}$ : İşgörenlerin algılanan örgütsel destekleri medeni duruma göre farklılık göstermektedir.

$\mathrm{H}_{4}$ : İşgörenlerin duygusal bağlıllıkları medeni duruma göre farklılık göstermektedir.

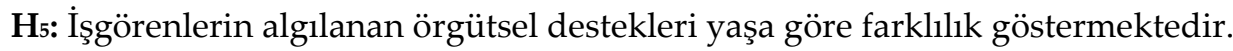

H6: İşgörenlerin duygusal bağlılıkları yaşa göre farklılık göstermektedir.

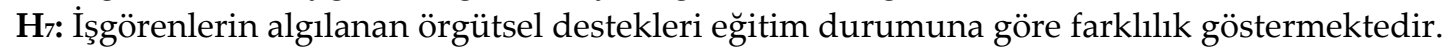

H8: İşgörenlerin duygusal bağlılıkları eğitim durumuna göre farklılık göstermektedir.

H9: İşgörenlerin algılanan örgütsel destekleri aylık gelire göre farklılık göstermektedir.

$\mathrm{H}_{10}$ : İşgörenlerin duygusal bağlılıkları aylık gelire göre farklılık göstermektedir.

H11: İşgörenlerin algılanan örgütsel destekleri ve duygusal bağlılıkları arasında pozitif yönlü bir ilişki vardır.

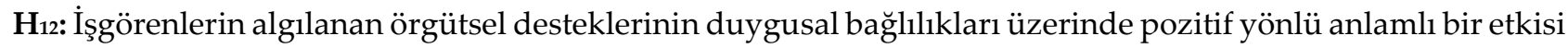
vardir.

\subsection{Evren ve Örneklem}

Bu araştırmanın evrenini 2019 yılında Mersin ilinde banka sektöründe istihdam edilen işgörenler oluşturmaktadır. Türkiye Bankalar Birliği tarafından yayınlanan istatistikî raporlara göre Mersin ilinde 2019 yılı itibariyle 2.393 kişi banka sektöründe çalışmaktadır (Türkiye Bankalar Birliği, 2020).

Zaman ve maliyet ile ilgili sınırlılıklar nedeniyle araştırma evreninin tamamından veri toplanamadığı için araştırma evrenini temsil edebilme gücüne sahip örneklem sayısını oluşturana kadar Mersin ilinde bulunan 19 banka şubesinden kolayda örnekleme yöntemiyle veri toplanmıştır. Mersin ilinde bulunan 19 banka şubesine 420 anket dağıtılmıştır. Veriler toplandıktan sonra 42 anketin boş bırakıldığı, 34 anketin eksik ve hatalı doldurulduğu tespit edilmiş ve araştırmaya 344 anket dâhil edilmiştir. Anket geri dönüş oranının \% 81,9 olduğu belirlenmiştir. Örneklem sayısının belirlenmesinde Gürbüz ve Şahin (2014: 126) tarafından farklı evrenler için kabul edilebilir asgari örneklem büyüklüklerini belirlemek amacıyla hazırlanan tablo referans olarak alınmıştır. Araştırma kapsamında, \% 95 güvenilirlik düzeyinde, örneklem büyüklüğünün (344 katılımc1) evreni temsil etme gücüne sahip, kabul edilebilir düzeyde ve yeterli sayıda olduğu kabul edilmiştir.

\subsection{Veri Toplama Araçları}

Araştırmada anket formu ile banka işgörenlerinden veri toplanmıştır. Anket formu 3 bölümden oluşmaktadır ve ilk bölümünde banka işgörenlerinin demografik özelliklerini belirlemeye yönelik sorular bulunmaktadır. İkinci bölümde, Eisenberger vd. (1986)'nin geliştirdiği algılanan örgütsel destek ölçeğinin Stassen ve Ursel 


\section{F. Keklik Okul 13/1 (2021) 464-480}

(2009)'in yaptıkları çalışma ile 10 ifadeye indirgenen kısaltılmış formu yer almaktadır. Son bölümde ise Meyer ve Allen (1991)'ın geliştirdiği ve Wasti (2000)'nin yaptı̆̆ çalışma ile Türkçe'ye uyarlanan örgütsel bağlılık ölçeğinin duygusal bağlılık boyutundaki ifadeler bulunmaktadır. Ölçekler aşağıda detaylı bir şekilde açıklanmıştır.

\subsubsection{Algılanan Örgütsel Destek Ölçeği}

Algılanan örgütsel destek ölçeği Eisenberger vd. (1986) tarafından geliştirilmiştir ve ölçek 36 ifadeden oluşmaktadır. Stassen ve Ursel (2009) yaptıkları çalışma sonucunda ölçeği 10 ifadeye indirgeyerek ölçeğin kısa formunu geliştirmişlerdir. Ölçeğin Türkçe'ye uyarlanması, geçerlilik ve güvenilirlik analizleri Akkoç vd. (2012) tarafından yapılmıştır. Akkoç vd. (2012) yaptıkları çalışmada ölçeğin faktör yüklerinin 0,76 ile 0,82 değerleri arasında olduğunu ve ölçeğin Cronbach's Alpha değerinin ise 0,93 olduğunu tespit etmişlerdir. Ölçekteki 6. ve 7. ifadelerde ters kodlama yapılmıştır. Ölçek 5'li derecelendirme şeklinde düzenlenmiştir ve ölçek yapısı; (1) Kesinlikle Katılmıyorum ile (5) Kesinlikle Katılıyorum şeklinde derecelendirilmiştir.

Bu araştırmada algılanan örgütsel destek ölçeğinin güvenilirliğini gösteren Cronbach's Alpha katsayısı 0,896 olarak hesaplanmıştır.

\subsubsection{Duygusal Bağlılık Ölçeği}

Duygusal bağlılık, Allen ve Meyer (1990: 845-854) tarafından geliştirilen üç boyutlu örgütsel bağlllı̆̆ın alt boyutlarından biridir. Bu nedenle araştırmada Meyer ve Allen (1991) tarafından geliştirilmiş olan "Örgütsel Bağllık Ölçeği" nin duygusal bağl1lık boyutuna ait ölçek ifadeleri kullanılmıştır. Ölçekteki ilk 6 ifade duygusal bağlılığı, 7.-12. ifadeler devamlılık bağlılığını, 13.-18. ifadeler ise normatif bağlılığı ölçmek için geliştirilmiştir. Ölçeğin Türkçe'ye uyarlanması, geçerlilik ve güvenilirlik analizleri Wasti (2000) tarafından yapılmıştır. Alt boyutlar bazında ölçeğin Cronbach Alfa değerlerinin; duygusal bağlllığın, 0,79, devamlılık bağlılığının 0,58 ve normatif bağlılığın ise 0,75 olduğu tespit edilmiştir. Ölçekteki 2., 4. ve 6. ifadeler ters kodlanmıştır. Ölçek, 7'li derecelendirme şeklinde düzenlenmiştir. Ölçek yapısı (1) Kesinlikle Katılmıyorum ile (7) Kesinlikle Katıliyorum şeklinde derecelendirilerek oluşturulmuştur.

$\mathrm{Bu}$ araştırmada duygusal bağlılık ölçeğinin güvenilirliğini gösteren Cronbach's Alpha katsayısının 0,799 olduğu tespit edilmiştir.

\subsection{Verilerin Analizi}

$\mathrm{Bu}$ araştırma iki değişken arasındaki ilişkiyi incelemek ve değişkenlerin demografik faktörler açısından farklılıklarını tespit etmek amacıyla yapılmıştır. Bununla birlikte araştırmada, evreni temsil eden örneklemden sayı ile ifade edilen sonuçlar ortaya konulmuştur. Bu nedenle araştırmada nicel araştırma yöntemlerinden bağıntısal ve nedensel karşılaştırma yöntemleri kullanılmıştır. Araştırma verileri anket formları aracılığıyla, kolayda örnekleme yöntemi kullanılarak toplanmıştır. Ölçeklerin güvenirliklerini tespit edebilmek için Cronbach's Alfa değerinden yararlanılmıştır. Verilerinin normal dağılımına uygunluğunu belirlemek amacıyla veri setinin çarpıklık ve basıklık değerleri incelenmiştir. Örneklem grubuna ilişkin tanımlayıcı istatistikler (frekans, aritmetik ortalama ve standart sapma değerleri) hesaplanmıştır. Örneklem grubunun algılanan örgütsel destek ve duygusal bağlllı̆̆ının cinsiyet ve medeni durum açısından farklılık gösterip göstermediğini incelemek için bağımsız gruplarda $t$ testi; yaş, eğitim durumu ve aylık gelir bakımından farklılıkların tespit edilmesi için ise tek yönlü varyans analizi (ANOVA) kullanılmıştır. Gruplar arasındaki farklılıkları incelemek için çoklu karşılaştırma analizlerinden Scheffe testi kullanılmıştır. Algılanan örgütsel desteğin duygusal bağlılık üzerindeki etkisini tespit etmek için basit regresyon analizinden yararlanılmıştır. Değişkenler arasındaki ilişkiyi incelemek için ise korelasyon analizi kullanılmıştır.

\section{BULGULAR}

Araştırma kapsamında verilerin analiz edilmesinde öncelikle ölçeklerin güvenirliliği ile verilerin normal dağılıma uygunluğu incelenmiştir. Algılanan örgütsel destek ölçeğinde yer alan ifadelerin çarpıklık değerleri -,260 ile ,930 arasında, basıklık değerleri -1,416 ile,581 arasında; duygusal bağlllık boyutundaki ifadelerin çarpıklık değerleri -,228 ile 465 arasında, basıklık değerleri ise -1,393 ile -,604 değerleri arasında değişmektedir. Byrne (2010: 104) verilerin basıklık değeri 5'ten küçük ise, Kline (2011: 63) çarpıklık değeri \pm 3 , basıklık değeri \pm 10 ise bu değerlerin normal dağılıma uygunluğun ölçütü olarak değerlendirilebileceğini ifade 


\section{F. Keklik Okul 13/1 (2021) 464-480}

etmişlerdir. Bu nedenle algılanan örgütsel destek ve duygusal bağlılı̆̆a ait verilerin normal dağılıma uygun olduğu kabul edilmiştir ve araştırmada parametrik testler uygulanmıştır. Aşağıdaki tabloda algılanan örgütsel destek (AÖD) ölçeğine ilişkin Cronbach's Alfa katsayısı ile çarpıklık ve basıklık değerleri yer almaktadır.

Tablo 1. AÖD Ölçeği Bazında Verilerin Çarpıklık ve Basıklık Değerleri ile Güvenilirliğine İlişkin Bulgular

\begin{tabular}{|c|c|c|c|c|}
\hline İfadeler & Çarpıklık & Basıklık & $\begin{array}{l}\text { Standart } \\
\text { Hata }\end{array}$ & $\begin{array}{l}\text { Cronbach's } \\
\text { Alfa }\end{array}$ \\
\hline 1-Çalıştığım kurum benim görüşlerimi dikkate alır. & 604 &,- 671 & ,06546 & \multirow{10}{*}{896} \\
\hline 2-Çalıştığım kurum gerçekten benim refahımı düşünür. & ,358 & ,581 & ,04938 & \\
\hline $\begin{array}{l}\text { 3-Çalıştığım kurum amaçlarımı ve değerlerimi çok fazla } \\
\text { önemser. }\end{array}$ & ,930 & 240 & ,05983 & \\
\hline $\begin{array}{l}\text { 4-Bir sorunum olduğunda, çalıştığım kurum bana çok fazla } \\
\text { yardımcı olur. }\end{array}$ & ,578 &,- 594 & ,05950 & \\
\hline $\begin{array}{l}\text { 5-Çalıştığım kurum, söz konusu ben olunca kabul edilebilir } \\
\text { hatalarımı bağışlar. }\end{array}$ & ,184 &,- 939 & ,06204 & \\
\hline 6-Çalıştığım kurum beni kendi çıkarı için kullanır. &,- 135 &,- 246 & ,05598 & \\
\hline 7-Çalıştığım kurum benim için çok az endişelenir. &,- 260 &,- 564 & ,05599 & \\
\hline $\begin{array}{l}\text { 8-Özel bir yardıma ihtiyaç duyduğumda çalıştığım kurum } \\
\text { bana yardım etmede istekli davranır. }\end{array}$ & 439 & $-1,416$ & ,07456 & \\
\hline 9-Çalıştığım kurum işteki başarılarımla gurur duyar. &,- 025 & $-1,027$ & 05914 & \\
\hline 10-Çalıştığım kurum işimi olabildiğince eğlenceli hale getirir. & ,393 &,- 816 & 06796 & \\
\hline
\end{tabular}

Tablo 1' de ölçeğin güvenilirliğini gösteren Cronbach's Alfa katsayısının 0,896 olduğu görülmektedir. Sosyal bilimler alanında "0,80 - 1.00" arasında çıkan Cronbach's Alfa değerlerinin çok yüksek derecede güvenilir olduğu belirtilmektedir (Kalaycı, 2008: 405). Araştırma kapsamında hesaplanan Cronbach's Alfa değeri $(0,896)$ ölçeğin çok yüksek derecede güvenilir olduğunu göstermektedir.

Tablo 2. DB Ölçeği Bazında Verilerin Çarpıklık ve Basıklık Değerleri ile Güvenilirliğine İlişkin Bulgular

\begin{tabular}{|c|c|c|c|c|}
\hline İfadeler & Çarpiklık & Basıklık & $\begin{array}{l}\text { Standart } \\
\text { Hata }\end{array}$ & $\begin{array}{l}\text { Cronbach's } \\
\text { Alfa }\end{array}$ \\
\hline $\begin{array}{l}\text { 1-Kariyerimin geri kalan kısmını bu işletmede geçirmek } \\
\text { beni mutlu eder. }\end{array}$ & ,465 &,- 604 & ,09149 & \multirow{6}{*}{,799 } \\
\hline $\begin{array}{l}\text { 2-Bu işletmeye kendimi "duygusal olarak bağlı" } \\
\text { hissetmiyorum. }\end{array}$ &,- 94 & $-1,195$ & ,09234 & \\
\hline $\begin{array}{l}\text { 3-Bu işletmenin sorunlarını gerçekten kendi sorunlarım } \\
\text { gibi hissederim. }\end{array}$ &,- 188 & $-1,285$ & ,08320 & \\
\hline $\begin{array}{l}\text { 4-Kendimi işletmemde "ailenin parçası" gibi } \\
\text { hissetmiyorum. }\end{array}$ &,- 006 & $-1,089$ & ,09763 & \\
\hline 5-Bu işletmenin benim için özel bir anlamı vardır. &,- 203 & $-1,069$ & 09534 & \\
\hline 6-İşletmeme karşı güçlü bir aitlik hissim yok. &,- 228 & $-1,393$ & 10001 & \\
\hline
\end{tabular}

Tablo 2' de duygusal bağlılık ölçeğinin Cronbach's Alfa katsayısının 0,799 olduğu görülmektedir ve tespit edilen değer ölçeğin yüksek derecede güvenilir olduğunu göstermektedir.

Banka işgörenlerinin demografik özelliklerine göre dağılımları aşağıdaki tabloda gösterilmektedir. 
F. Keklik Okul 13/1 (2021) 464-480

Tablo 3. Örneklem Grubuna İlişkin Tanımlayıcı İstatistikler

\begin{tabular}{|c|c|c|c|}
\hline Değişken & Kategori & Frekans (f) & Yüzde (\%) \\
\hline \multirow{3}{*}{ Cinsiyet } & Kadın & 160 & 46,5 \\
\hline & Erkek & 184 & 53,5 \\
\hline & Toplam & 344 & 100 \\
\hline \multirow{3}{*}{ Medeni Durum } & Evli & 201 & 58,4 \\
\hline & Bekar & 143 & 41,6 \\
\hline & Toplam & 344 & 100 \\
\hline \multirow{5}{*}{ Yaş } & 18-29 yaş aralığ1 & 83 & 24,1 \\
\hline & 30-39 yaş aralığ 1 & 185 & 53,8 \\
\hline & $40-49$ yaş aralı̆̆ & 50 & 14,5 \\
\hline & 50 yaş ve üzeri & 26 & 7,6 \\
\hline & Toplam & 344 & 100 \\
\hline \multirow{4}{*}{ Aylık Gelir } & 2000-3000 TL & 99 & 28,8 \\
\hline & 3001-4000 TL & 166 & 48,3 \\
\hline & 4001 TL ve Üzeri & 79 & 23,0 \\
\hline & Toplam & 344 & 100 \\
\hline \multirow{4}{*}{ Eğitim Durumu } & Ön lisans & 29 & 8,4 \\
\hline & Lisans & 289 & 84,0 \\
\hline & Lisansüstü & 26 & 7,6 \\
\hline & Toplam & 344 & 100 \\
\hline
\end{tabular}

Tablo 3’ de görüleceği üzere işgörenlerin \%46,5'i (160 kişi) kadın, \%53,5'si (184 kişi) erkektir. Medeni duruma göre işgörenlerin \%58,4'ü evli (201 kişi), \%41,6'sı (143 kişi) bekardır. İşgörenler yaş gruplarına göre incelendiğinde, \%24,1'inin (83 kişi) 18-29 yaş, \%53,8'inin (185 kişi) 30-39 yaş, \%14,5'inin (50 kişi), 40-49 yaş arasında ve \%7,6'sının ise (26 kişi) 50 yaş ve üzerinde olduğu görülmektedir. İşgörenlerin \%28,8'i (99 kişi) 2000-3000 TL arası, \%48,3'ü (166 kişi) 3001-4000 TL arası, \%23'ü (79 kişi) ise 4001 TL ve üzeri aylık gelire sahiptir. Eğitim durumuna göre işgörenlerin \%8,4’ü (29 kişi) ön lisans, \%84'ünün (289 kişi) lisans ve \%7,6'sının (26 kişi) ise lisansüstü programlardan mezun olduğu tespit edilmiştir.

Tablo 4. Ölçeklere İlişkin Açıklayıcı İstatistikler

\begin{tabular}{lccccc}
\hline & $\mathbf{N}$ & Min. & Mak. & Ortalama & Standart Sapma \\
\hline AÖD & 344 & 1 & 5 & 3,099 &, 90021 \\
\hline DB & 344 & 1 & 5 & 2,900 &, 87331 \\
\hline
\end{tabular}

Tablo 4'te görüleceği üzere banka işgörenlerinin algılanan örgütsel destek düzeylerinin $(X=3,09)$ ve duygusal bağlllık düzeylerinin $(X=2,90)$ orta seviyede olduğu tespit edilmiştir.

Banka işgörenlerinin algılanan örgütsel destek ölçeğindeki ifadelere verdikleri cevaplara ilişkin açıklayıcı istatistikler aşağıdaki tabloda bulunmaktadır. 
Tablo 5. Algılanan Örgütsel Destek Ölçeğine İlişkin Açıklayıcı İstatistikler

İfadeler

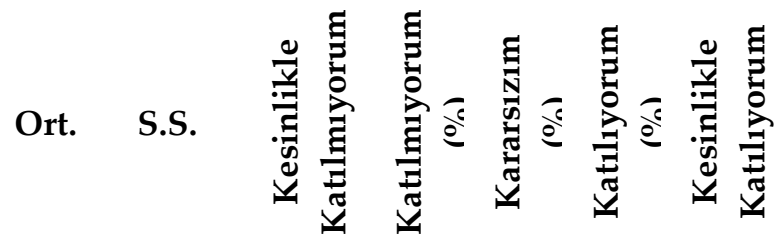

\begin{tabular}{|c|c|c|c|c|c|c|c|}
\hline 1-Çalıştığım kurum benim görüşlerimi dikkate alır. & 2,825 & 1,214 & 8,7 & 41,0 & 25,9 & 7,8 & 16,6 \\
\hline $\begin{array}{l}\text { 2-Çalıştığım kurum gerçekten benim refahımı } \\
\text { düşünür. }\end{array}$ & 2,689 & ,9158 & 10,6 & 31,1 & 45,3 & 9,3 & 3,7 \\
\hline $\begin{array}{l}\text { 3-Çalıştığım kurum amaçlarımı ve değerlerimi çok } \\
\text { fazla önemser. }\end{array}$ & 2,627 & 1,109 & 9,3 & 46,2 & 29,7 & 2,0 & 12,8 \\
\hline $\begin{array}{l}\text { 4-Bir sorunum olduğunda, çalıştığım kurum bana } \\
\text { çok fazla yardımcı olur. }\end{array}$ & 2,918 & 1,103 & 4,5 & 39,1 & 31,1 & 11,6 & 13,7 \\
\hline $\begin{array}{l}\text { 5-Çalıştığım kurum, söz konusu ben olunca kabul } \\
\text { edilebilir hatalarımı bağışlar. }\end{array}$ & 3,215 & 1,150 & 4,2 & 25,9 & 34,0 & 16,6 & 19,6 \\
\hline 6-Çalıştığım kurum beni kendi çıkarı için kullanır. & 3,418 & 1,038 & 4,7 & 8,7 & 45,6 & 22,1 & 18,9 \\
\hline 7-Çalıştığım kurum benim için çok az endişelenir. & 3,485 & 1,030 & 2,9 & 14,5 & 31,7 & 32,8 & 18,0 \\
\hline $\begin{array}{l}\text { 8-Özel bir yardıma ihtiyaç duyduğumda çalışı̆̆ı̆ } \\
\text { kurum bana yardım etmede istekli davranır. }\end{array}$ & 3,05 & 1,382 & 4,1 & 25,9 & 34,1 & 16,7 & 19,3 \\
\hline 9-Çalıştı̆̆ım kurum işteki başarılarımla gurur duyar. & 3,375 & 1,096 & 2,0 & 23,7 & 27,9 & 27,7 & 18,6 \\
\hline $\begin{array}{l}\text { 10-Çalıştığım kurum işimi olabildiğince eğlenceli } \\
\text { hale getirir. }\end{array}$ & 2,758 & 1,260 & 16,3 & 31,4 & 26,5 & 11,9 & 14,0 \\
\hline
\end{tabular}

Tablo 5' te, "Çalıştı̆̆ım kurum benim için çok az endişelenir" $(3,485)$ ifadesinin algılanan örgütsel destek ölçeğindeki ortalama değeri en yüksek olan ifade olduğu ve "Çalıştığım kurum amaçlarımı ve değerlerimi çok fazla önemser" $(2,627)$ ifadesinin ise en düşük ortalama değere sahip olduğu görülmektedir. Diğer yandan işgörenlerin en az katıldıkları ifadenin "Çalıştığım kurum işteki başarılarımla gurur duyar" (\%2); en fazla katıldıkları ifadenin ise "Çalıştığım kurum benim için çok az endişelenir" (\%32) olduğu tespit edilmiştir.

Tablo 6. Duygusal Bağlllık Ölçeğine İlişkin Açılayıcı İstatistikler

\begin{tabular}{|c|c|c|c|c|c|c|c|}
\hline İfadeler & Ort. & S.S. & 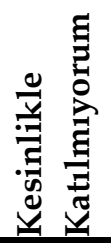 & 急 & 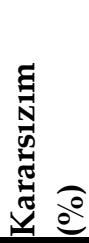 & 远 & 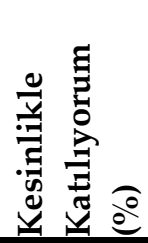 \\
\hline $\begin{array}{l}\text { 1- Kariyerimin geri kalan kısmını bu işletmede } \\
\text { geçirmek beni mutlu eder. }\end{array}$ & 2,784 & 1,214 & 9,0 & 44,8 & 19,8 & 11,6 & 14,8 \\
\hline $\begin{array}{l}\text { 2- Bu işletmeye kendimi "duygusal olarak bağlı" } \\
\text { hissetmiyorum. }\end{array}$ & 2,970 & 1,245 & 9,6 & 38,1 & 9,9 & 30,5 & 11,9 \\
\hline $\begin{array}{l}\text { 3- Bu işletmenin sorunlarını gerçekten kendi } \\
\text { sorunlarım gibi hissederim. }\end{array}$ & 3,162 & 1,285 & 3,8 & 35,8 & 10,5 & 40,4 & 9,6 \\
\hline $\begin{array}{l}\text { 4- Kendimi işletmemde "ailenin parçası" gibi } \\
\text { hissetmiyorum. }\end{array}$ & 2,828 & 1,287 & 21,5 & 19,2 & 23,3 & 27,0 & 9,0 \\
\hline 5- Bu işletmenin benim için özel bir anlamı vardır. & 3,384 & 1,061 & 3,5 & 25,6 & 14,0 & 48,0 & 9,0 \\
\hline 6- İşletmeme karşı güçlü bir aitlik hissim yok. & 3,014 & 1,276 & 6,1 & 43,0 & 13,4 & 18,3 & 19,2 \\
\hline
\end{tabular}

Tablo 6'da, duygusal bağlılık ölçeğindeki "Bu işletmenin benim için özel bir anlamı vardır” $(3,384)$ ifadesinin ortalama değerinin en yüksek olduğu ve "Kariyerimin geri kalan kısmını bu işletmede geçirmek beni mutlu 


\section{F. Keklik Okul 13/1 (2021) 464-480}

eder" $(2,784)$ ifadesinin en düşük ortalama değere sahip olduğu görülmektedir. Diğer yandan işgörenlerin en az katıldıkları ifadenin "İşletmeme karşı güçlü bir aitlik hissim yok", $(\% 6,1)$ ve en fazla katıldıkları ifadenin ise "Bu işletmenin benim için özel bir anlamı vardır" (\%48) olduğu tespit edilmiştir.

\subsubsection{Demografik Faktörlere Göre Farklılıkların Analizine İlişkin Bulgular}

İşgörenlerin algılanan örgütsel destek ve duygusal bağlılıklarının cinsiyete göre farklılıklarının incelenmesi için yapılan $t$ testi sonuçları aşağıdaki tabloda bulunmaktadır.

Tablo 7. Cinsiyete Göre Farklılıkların Tespiti İcin t testi

\begin{tabular}{llccccc}
\hline & Cinsiyet & $\mathbf{N}$ & Ortalama & Standart Sapma & $\mathbf{t}$ & $\mathbf{p}$ \\
\hline \multirow{2}{*}{ AÖD } & Kadın & 160 & 2,8381 &, 76638 & $-1,231$ & 0,219 \\
& Erkek & 184 & 2,9542 &, 95543 & & \\
\hline \multirow{2}{*}{ DB } & Kadın & 160 & 3,1240 &, 78481 & \multirow{2}{*}{, 471} & 0,638 \\
& Erkek & 184 & 3,0788 &, 99130 & & \\
\hline
\end{tabular}

Tablo 7'de işgörenlerin algılanan örgütsel destek ve duygusal bağlllıklarının cinsiyetlerine göre anlamlı bir şekilde farklılaşmadığı görülmektedir $(\mathrm{p}>0,05)$. Bu nedenle "Hı: İşgörenlerin örgütsel destek algıları cinsiyetlerine göre farklılık göstermektedir" ile " $\mathbf{H}_{2}$ : İşgörenlerin duygusal bağl1lıkları cinsiyetlerine göre farklılık göstermektedir" reddedilmiştir.

Tablo 8. Medeni Duruma Göre Farklılıkların Tespiti İçin $\mathrm{t}$ testi

\begin{tabular}{llccccc}
\hline & Medeni Durum & N & Ortalama & Standart Sapma & $\mathbf{t}$ & $\mathbf{P}$ \\
\hline \multirow{2}{*}{ AÖD } & Evli & 201 & 3,029 &, 7618 & 3,609 & $\mathbf{0 , 0 0 0}$ \\
\hline DB & Bekar & 143 & 2,581 &, 8058 & & \\
& Evli & 91 & 3,4121 &, 75204 & 8,359 & $\mathbf{0 , 0 0 0}$ \\
& Bekar & 70 & 2,6608 &, 91038 & & \\
\hline
\end{tabular}

Tablo 8'de işgörenlerin medeni duruma göre algılanan örgütsel destek ve duygusal bağlılıklarının anlamlı şekilde farklılaştığı görülmektedir $(\mathrm{p}<0,05)$. İşgörenlerden evli olanların algılanan örgütsel destek ile duygusal bağlllıklarının bekar işgörenlere göre daha yüksek düzeyde olduğu tespit edilmiştir. “H3: İşgörenlerin örgütsel destek algıları medeni duruma göre farklılık göstermektedir" ile "H4: İşgörenlerin duygusal bağlllıkları medeni duruma göre farklılık göstermektedir" kabul edilmiştir.

\subsubsection{Tek Yönlü Varyans Analizi (ANOVA) Bulguları}

Banka işgörenlerinin bulundukları yaş gruplarına göre algılanan örgütsel destek ve duygusal bağlılıklarının farklılaşıp farklılaşmadığını gösteren ANOVA analizi tablosu aşağıda bulunmaktadır.

Tablo 9. Yaş Gruplarına Göre Farklılıkların Tespiti İçin ANOVA Analizi

\begin{tabular}{llccccc}
\hline & Yaş Grubu & N & Ort. & S.S. & F & p \\
\hline \multirow{4}{*}{ AÖD } & 18-29 yaş aralı̆̆1 & 83 & 3,1099 &, 79452 & & \\
& 30-39 yaş aralığ1 & 184 & 2,9155 &, 94119 & & \\
& '40-49 yaş aralığ1 & 51 & 2,7480 &, 43483 & 4,969 & $\mathbf{0 , 0 0 2}$ \\
& 50 yaş ve üzeri & 26 & 2,4144 & 1,0317 & & \\
& Toplam & 344 & 2,9002 &, 87331 & & \\
DB & 18-29 yaş aralığ1 & 83 & 2,6847 &, 73943 & & \\
& 30-39 yaş aralığ1 & 184 & 3,2225 &, 94738 & & \\
& 40-49 yaş aralığ1 & 51 & 3,2000 &, 88256 & 8,472 & $\mathbf{0 , 0 0 0}$ \\
& 50 yaş ve üzeri & 16 & 3,3590 &, 64755 & & \\
\hline
\end{tabular}

$\bar{p}<0,05$ 


\section{F. Keklik Okul 13/1 (2021) 464-480}

Tablo 9'da işgörenlerin örgütsel destek algıları ile duygusal bağlllıklarının yaşa göre anlamlı bir şekilde farklılaştığı görülmektedir $(\mathrm{p}<0,05)$. Farklılık gösteren grupları incelemek için yapılan Scheffe testinin sonuçları aşağıdaki tabloda yer almaktadır.

Tablo 10. Algılanan Örgütsel Destek Ölçeği Bazında Yaşa Göre Çoklu Karşılaştırma

\begin{tabular}{ccccc}
\hline Yaş (I) & Yaş (J) & Ortalama Farkları (I-J) & Standart Hata & p \\
\hline $18-29$ yaş aralı̆̆ı & 50 yaş ve üzeri &, $69552^{*}$ &, 19295 &, 005 \\
\hline
\end{tabular}

$\mathrm{p}<0,05$

Tablo 10'da, 18-29 yaş aralığında olan işgörenlerin algılanan örgütsel destek düzeylerinin 50 yaş ve üzeri olanlara göre daha yüksek olduğu görülmektedir ve "Hs: İşgörenlerin örgütsel destek algıları yaşa göre farklılık göstermektedir" hipotezi kabul edilmiştir.

Tablo 11. Duygusal Bağlılık Ölçeğinde Yaşa Göre Çoklu Karşılaştırma

\begin{tabular}{ccccc}
\hline Yaş (I) & Yaş (J) & Ortalama Farkları (I-J) & $\begin{array}{c}\text { Standart } \\
\text { Hata }\end{array}$ & p \\
\hline \multirow{3}{*}{$18-29$ yaş } & 30-39 yaş aralığı &,$- 53778^{*}$ &, 11522 &, $\mathbf{0 0 0}$ \\
& 40-49 yaş aralığ &, 15614 &, 15614 &, $\mathbf{0 1 3}$ \\
& 50 yaş ve üzeri &,$- 67424^{*}$ &, 19601 &, 009 \\
\hline
\end{tabular}

$\mathrm{p}<0,05$

Tablo 11'de, 18-29 yaş aralığında olan işgörenlerin duygusal bağlllıklarının diğer yaş gruplarından daha düşük düzeyde olduğu görülmektedir. Bu sonuç doğrultusunda " $\mathbf{H}_{6}$ : İşgörenlerin duygusal bağlılıkları yaşa göre farklılık göstermektedir" hipotezi kabul edilmiştir.

Tablo 12. Eğitim Durumuna Göre Farklılıkların Tespiti İçin ANOVA Analizi

\begin{tabular}{lllcccc}
\hline & Eğitim Durumu & $\mathbf{N}$ & Ortalama & $\begin{array}{c}\text { Standart } \\
\text { Sapma }\end{array}$ & F & p \\
\hline \multirow{4}{*}{ AÖD } & Ön Lisans & 29 & 3,509 &, 9441 & & \\
& Lisans & 289 & 2,871 &, 8485 & 9,887 & $\mathbf{0 , 0 0 0}$ \\
& Lisansüstü & 26 & 2,542 &, 7727 & & \\
& Toplam & 344 & 2,900 &, 8733 & & \\
& Ön Lisans & 29 & 3,752 &, 9570 & & \\
& Lisans & 289 & 3,028 &, 8766 & & $\mathbf{0 , 0 0 0}$ \\
& Lisansüstü & 26 & 3,160 &, 8266 & 8,988 & \\
& Toplam & 344 & 3,099 &, 9002 & & \\
\end{tabular}

$\overline{\mathrm{p}}<0,05$

Tablo 12' de, banka işgörenlerinin algılanan örgütsel destek ve duygusal bağlllıklarının eğitim durumlarına göre anlamlı bir şekilde farklılaştı̆̆ görülmektedir $(\mathrm{p}<0,05)$. Ĕ̆itim durumuna göre farklılık gösteren grupları incelemek için yapılan Scheffe testinin sonuçları aşağıdaki tabloda bulunmaktadır.

Tablo 13. Algılanan Örgütsel Destek Ölçeğinde Eğitim Durumuna Göre Çoklu Karşılaştırma

\begin{tabular}{lcccc}
\hline Eğitim Durumu (I) & Eğitim Durumu (J) & Ortalama Farkları (I-J) & Standart Hata & p \\
\hline \multirow{2}{*}{ Ön Lisans } & Lisans &, $63820^{*}$ &, 16587 &, 001 \\
\cline { 2 - 5 } & Lisansüstü &, $96718^{*}$ &, 22998 &, 000 \\
\hline${ }^{*} \mathrm{p}<0,05$ & & &
\end{tabular}




\section{F. Keklik Okul 13/1 (2021) 464-480}

Tablo 13'te, ön lisans programlarından mezun olan işgörenlerin algılanan örgütsel destek düzeylerinin lisans ve lisanüstü programlardan mezun olanlara göre daha yüksek olduğu görülmektedir. Bu sonuç doğrultusunda "H7: İşgörenlerin algılanan örgütsel destekleri eğitim durumuna göre farklılık göstermektedir" kabul edilmiştir.

Tablo 14. Duygusal Bağlllık Ölçeğinde Eğitim Durumuna Göre Çoklu Karşılaştırma

\begin{tabular}{ccccc}
\hline Eğitim Durumu (I) & Eğitim Durumu (J) & Ortalama Farkları (I-J) & Standart Hata & p \\
\hline \multirow{2}{*}{ Ön Lisans } & Lisans &, $72404^{*}$ &, 17141 &, 000 \\
\cline { 2 - 5 } & Lisansüstü &, $59262^{*}$ &, 23766 &, 046 \\
\hline
\end{tabular}

$\mathrm{p}<0,05$

Tablo 14'te, ön lisans mezunlarının duygusal bağlılık düzeylerinin lisans ve lisanüstü programlardan mezun olanlardan daha yüksek olduğu görülmektedir. Bu sonuç doğrultusunda "Hs: “İşgörenlerin duygusal bağll1ıkları eğitim durumuna göre farklılık göstermektedir" hipotezi kabul edilmiştir.

Tablo 15. Aylık Gelire Göre Farklılıkların Tespiti İçin ANOVA Analizi

\begin{tabular}{rlrrrrr}
\hline \multicolumn{1}{c}{ Gelir } & N & Ortalama & SS & F & p \\
\hline \multirow{4}{*}{ AÖD } & 2000-3000 TL & 99 & 3,152 &, 71284 & & \\
& 3001-4000 TL & 166 & 2,809 &, 98977 & 6,012 & $\mathbf{0 , 0 0 3}$ \\
& 4001 ve Üzeri & 79 & 2,775 &, 90220 & & \\
& Toplam & 344 & 2,900 &, 90021 & & \\
& 2000-3000 TL & 99 & 2,967 &, 6560 & & \\
& 3001-4000 TL & 166 & 3,188 &, 8488 & 1,882 & $\mathbf{0 , 1 5 4}$ \\
DB & 4001 TL ve Üzeri & 79 & 3,075 &, 9049 & & \\
& Toplam & 344 & 3,099 &, 8270 & & \\
& & & & & \\
\end{tabular}

Tablo 15’te görüleceği üzere işgörenlerin duygusal bağlılıklarının aylık gelirlerine göre farklılaşmadığı ancak algılanan örgütsel desteğin aylık gelire göre anlamlı bir şekilde farklılık gösterdiği tespit edilmiştir. Aylık gelire göre farklılık gösteren grupları belirlemek amacıyla yapılan Scheffe testinin sonuçları aşağıdaki tabloda bulunmaktadir.

Tablo 16. Algılanan Örgütsel Destek Ölçeği Bazında Aylık Gelir Durumuna Göre Çoklu Karşılaştırma

\begin{tabular}{clclc}
\hline Gelir (I) & Gelir (J) & Ortalama Farkları (I-J) & St. Hata & p \\
\hline \multirow{2}{*}{ 2000-3000 TL } & $3001-4000 \mathrm{TL}$ &, $34334^{*}$ &, 10931 & $\mathbf{0 , 0 0 8}$ \\
\cline { 2 - 5 } & $4001 \mathrm{TL}$ ve üzeri &, $37721^{*}$ &, 12986 &, $\mathbf{0 1 5}$ \\
\hline
\end{tabular}

${ }^{*} \mathrm{p}<0,05$

Tablo 16'da, 2000-3000 TL arası aylık gelire sahip olan banka işgörenlerinin algılanan örgütsel destek düzeylerinin 4001 TL ve üzeri ile 3001-4000 TL arası aylık gelire sahip olanlardan daha yüksek düzeyde olduğu görülmektedir. Verilen bilgiler doğrultusunda "H9: İşgörenlerin örgütsel destek algıları aylık gelire göre farklılık göstermektedir" hipotezi kabul edilmiştir. "Hı: İşgörenlerin duygusal bağlllıkları aylık gelire göre farklılık göstermektedir" hipotezi reddedilmiştir.

\subsubsection{Değişkenler Arasındaki İlişkilerin Tespit Edilmesi}

$\mathrm{Bu}$ araştırma kapsamında değişkenler arasındaki ilişkinin yönü ve derecesi korelasyon analizi ile incelenmiştir. Veriler normal dağılıma uygun olduğu için iki değişken arasındaki ilişkilerin yönü ve derecesi korelasyon analizinde bulunan Pearson korelasyon katsayısı (r) ile değerlendirilmiştir. Algılanan örgütsel destek (AÖD) ve duygusal bağlılık (DB) arasındaki ilişkiyi gösteren korelasyon analizi sonuçları aşağıdaki tabloda bulunmaktadır. 
Tablo 17. AÖD ile DB Arasındaki İlişkiyi Gösteren Korelasyon Analizi Bulguları

\begin{tabular}{lccc}
\hline Değişken & AÖD & DB \\
\hline Algılanan Örgütsel Destek (AÖD) & $\begin{array}{c}\text { Pearson } \\
\text { Corelation } \\
\text { Sig(2-tailed) }\end{array}$ & 1 &, $482^{* *}$ \\
\hline Duygusal Bağlılık (DB) & $\begin{array}{c}\text { Pearson } \\
\text { Corelation } \\
\text { Sig(2-tailed) }\end{array}$ &, $482^{* *}$ & 1 \\
\hline
\end{tabular}

** $\mathrm{p}<0,01$

Tablo 17'deki analiz sonuçları algılanan örgütsel destek ve duygusal bağlılık arasında anlamlı ve pozitif yönlü zayıf bir ilişki olduğunu göstermektedir $(r=0,482 ; p<0,01)$. Bu sonuç banka işgörenlerinin örgütlerine karşı duygusal bağlılıkları arttıkça algılanan örgütsel destek düzeylerinin arttığını, algılanan örgütsel destek düzeyi arttıkça da duygusal bağlılıklarının arttı̆̆ını göstermektedir. Verilen bilgiler doğrultusunda “Hı̈: İşörenlerin algılanan örgütsel destek ve duygusal bağlılıkları arasında pozitif yönlü bir ilişki vardır" kabul edilmiştir.

Algılanan örgütsel desteğin duygusal bağlılık üzerindeki etkisini incelemek amacıyla yapılan regresyon analizinde, bağımsız değişken algılanan örgütsel destek (AÖD) ve bağımlı değişken olarak ise duygusal bağlılık (DB) incelenmiştir. Regresyon analizi sonuçları aşağıdaki tabloda bulunmaktadır.

Tablo 18. AÖD'nin DB'ye Etkisini Gösteren Regresyon Analizi Tablosu

\begin{tabular}{lcccccc}
\hline $\begin{array}{l}\text { Bağımlı Değişken: } \\
\text { DB }\end{array}$ & $\mathbf{B}$ & $\begin{array}{c}\text { Standart } \\
\text { Hata }\end{array}$ & $\boldsymbol{\beta}$ & $\mathbf{p}$ & $\mathbf{R}$ & $\mathbf{t}$ \\
\hline Sabit & 1,658 &, 202 & \multirow{2}{*}{, 482} &, 000 &, 232 & 11,213 \\
\hline AÖD &, 497 &, 068 & & & & 10,178 \\
\hline
\end{tabular}

$\mathrm{p}<0,01$

Tablo 18 incelendiğinde, $\mathrm{p}<0,01$ anlamlılık düzeyinde ve \% 5 güven aralığında algılanan örgütsel desteğin $(B=, 497, p<0,01)$ duygusal bağlllık üzerinde pozitif yönlü anlamlı etkisi olduğu görülmektedir. Regresyon modelinin açılama gücünü ifade eden belirlilik katsayısına göre, duygusal bağlılık \%23,2 oranında algılanan örgütsel destek tarafından açıklanabilmektedir. Bu sonuç işgörenlerin duygusal bağlılıklarının \%23,2'lik kısmının örgütsel destek algısına bağlı olduğunu ve işgörenlerin örgütteki destek algıları arttıkça, duygusal bağlılık düzeylerinin de arttığını göstermektedir. Verilen bilgiler doğrultusunda $\mathbf{H}_{12}$ : İşgörenlerin algılanan örgütsel desteklerinin duygusal bağlılıkları üzerinde pozitif yönlü anlamlı bir etkisi vardır. hipotezi kabul edilmiştir.

\section{SONUÇ ve TARTIŞMA}

Algılanan örgütsel destek ile duygusal bağlılık arasındaki ilişkilerin demografik faktörler bağlamında ele alındığı bu çalışmada alanyazından edinilen bilgiler doğrultusunda 12 temel hipotez geliştirilmiştir. Hipotezlerin çıkış noktası örgütler için önemli bir değer olan duygusal bağlılığın arttırılmasında, algılanan örgütsel desteğin etkili olabileceği düşüncesine dayanmaktadır. Bununla birlikte algılanan örgütsel desteğin ve duygusal bağlılığın bireye özgü olarak düşünsel ve duygusal boyutta oluşan kavramlar olması nedeniyle her iki kavramın da demografik faktörlere göre farklılaşabileceği düşüncesinden hareketle araştırma gerçekleştirilmiştir. Çalışmada banka işgörenlerinin algılanan örgütsel destek düzeylerinin $(3,09)$ ve duygusal bağlllıklarının $(2,90)$ orta düzeyde olduğu tespit edilmiştir. Araştırma bulguları algılanan örgütsel desteğin medeni durum, eğitim durumu, yaş ve aylık gelire göre; duygusal bağlılı̆̆ın ise medeni durum, eğitim durumu ve yaşa göre farklılaştığını göstermektedir. Diğer yandan araştırmada, banka işgörenlerinin örgütsel destek algılarının artması ile duygusal bağlılık düzeylerinin de arttığı tespit edilmiştir. Araştırma bulgusu alanyazınla paralellik göstermektedir. Eisenberger vd., (1990), Shore ve Wayn (1993), Greenberg (1994), 


\section{F. Keklik Okul 13/1 (2021) 464-480}

Roades vd., (2001), Özdevecioğlu (2003), Kaplan (2010), Marique vd., (2012), Gürbüz (2012), Heffernan ve Dunlon (2016), Kim vd., (2016), Kurtessis vd., (2017), Kenek (2017) ve Özakar (2019) tarafından yapılan çalışmalarda da değişkenler arasında anlamlı ilişkiler olduğu ortaya konulmuştur. Araştırma kapsamında örgütsel destek algısının duygusal bağllık üzerinde pozitif yönde etkisi olduğu tespit edilmiştir. İlgili alanyazın incelendiğinde araştırma bulgusunun alanyazınla paralellik gösterdiği görülmektedir. Shore ve Tetrick (1991), Köse ve Gönüllüoğlu (2010), Üren ve Çorbacioğlu (2012), Altaş (2019), Özakar (2019) ve Sherwani (2019) tarafından yapılan çalışmalarda da benzer araştırma bulgularına ulaşılmıştır. Bu araştırmalardan elde edilen bulgular; örgütlerde örgütsel destek algısını oluşturan mekanizmaların işgörenler tarafından olumlu algılandığı takdirde işgörenlerin daha fazla duygusal bağlılık gösterme potansiyeli olduğuna ve örgütlerin destek algısını geliştirmek amacıyla gösterecekleri çabanın duygusal bağlılığı geliştirmek açısından önemli olduğunu vurgulamaktadır.

Örgütlerde daha etkin ve üretken bir şekilde işleyen bir sistem oluşturabilmek ve bunu devam ettirebilmek amacıyla, yöneticilerin öncelikle örgütte bilgi paylaşımına ve iletişime önem vermeleri, karar alma sürecinde işgörenlerinin öneri, şikâyet ve görüşlerini göz önünde bulundurmaları, örgüt içerisinde işgörenlerinin refahının önemsendiğine dair algı oluşturmaları, işgörenlerin örgüte olan katkılarını takdir etmeleri, performanslarını adil bir şekilde değerlendirilmeleri ve başarıyı ödüllendirmelerinin örgütsel destek algısının oluşmasına katkıda bulunacağı öngörülmektedir.

Daha sonraki yapılacak çalışmalarda algılanan örgütsel destek ve duygusal bağllı̆̆g etkisi olabilecek birey ve örgüt düzeyindeki faktörlerin araştırılmasının alanyazın ve uygulayıcılar için faydalı olacağı düşünülmektedir. Bu doğrultuda stres, psikolojik dayanıklılık, öz yeterlilik inancı ve kişilik özellikler gibi bireysel düzeydeki değişkenlerin algılanan örgütsel destek ve duygusal bağlılığa etkisinin araştırılmasının yanı sıra örgüt içi politikalar, örgütsel adalet, iş performansı, işe angaje olma, psikolojik güçlendirme, örgüt içi güven ortamı ve örgüt kültürü gibi örgüt düzeyindeki değişkenlerin de etkileri araştırılabilir. Ayrıca konuyla ilgili yürütülen araştırmaların sağlık, eğitim, gıda ve beslenme, konaklama sektörü, ulaştırma hizmetleri gibi farklı sektörlerde örneklem sayısı arttırılarak tekrarlanmasının daha önce yapılan araştırmaları desteklemek açısından önemli olacağı öngörülmektedir.

\section{KAYNAKÇA}

Allen, M.W., Armstrong, D.J., Reid, M.F. and Riemenschneider, C.K. (2008). Factors impacting the perceived organizational support of IT employees, Information \& Management, 45, 556-563.

Allen, N. J. and Meyer, J. P. (1990). The measurement and antecedents of affective, continuance, and normative commitment to the organization. Journal of Occupational Psychology, 63, 1-18.

Altaş, S. S. (2019). Çalışanların algıladıkları örgütsel desteğin duygusal bağlılık ve iş tatmini üzerindeki etkisi, Uluslararası Sosyal Araştırmalar Dergisi, 12(64), 845-854.

Aykan, E. (2007). Örgütlerde insan kaynakları uygulamaları ile AÖD arasındaki ilişkilerin belirlenmesine yönelik bir araştırma, Dokuz Eylül Üniversitesi İktisadi ve İdari Bilimler Fakültesi Dergisi, 22(1), 123-137.

Balay, R. (2000). Özel ve resmi liselerde yönetici ve öğretmenlerin örgütsel bağhllı̆̆r: Ankara ili örneği, Yayınlanmamış Doktora Tezi, Ankara Üniversitesi Sosyal Bilimler Enstitüsü, Ankara.

Beckers, D.G.J., Van Der Linden, D., Smulders, P.G.W., Kompier, M.A.J., Van Veldhoven, M.J.P.M., and Van Yperen, N.W., (2004). Working overtime hours: Relations with fatigue, work motivation, and the quality of work", Journal of Occupational and Environmental Medicine, 46(12): 1282- 1288.

Bozkurt, F. (2007). Denizcilik sektöründe çalışan gemi adamlarının demografik özellikleri ile örgütsel bağhllık, örgütsel vatandaşlık davranışı ve algılanan örgütsel destek düzeyi arasındaki ilişkiyi incelemeye yönelik bir araştırma, Yayımlanmamış Yüksek Lisans Tezi, Celal Bayar Üniversitesi Sosyal Bilimler Enstitüsü, Manisa.

Byrne, B. M. (2010). Structural equation modeling with amos, Routledge Taylor \& Francis Group, Newyork. 


\section{F. Keklik Okul 13/1 (2021) 464-480}

Chen, Zhen X., Aryee, S. and Lee, C. (2005). Test of A mediation model of perceived organizational support, Journal of Vocational Behavior, 66: 457-460.

Çekmecelioğlu, H. (2006). İş tatmini ve örgütsel bağlılık tutumlarının işten ayrılma niyeti ve verimlilik üzerindeki etkilerinin değerlendirilmesi: Bir araştırma, Isguc The Journal Of Industrial Relations And Human Resources, 8(2), 153-168.

Doğan, S. ve Kılıç, S. (2008). Örgütsel bağlılığın sağlanmasında personel güçlendirmenin yeri ve önemi, Erciyes Üniversitesi İktisadi ve İdari Bilimler Fakültesi Dergisi, 29, 37-61.

Demirkol, A. Y. (2014). Eğitim kurumlarında örgütsel bağlılık: Meslek yüksekokulları üzerine bir araştırma, Eğitim Bilimleri Araştırmaları Dergisi, 1-15.

Edwards, M. R., and Peccei, R. (2010). Perceived organizational support, organizational identification and employee outcomes: Testing a simultaneous multifoci model. Journal of Personnel Psychology, 9(1), 1726.

Eisenberger, R., Huntingtton, R., Hutchison, S., and Sowa, D. (1986). Perceived organizational support, Journal of Applied Psychology, 71, 500-507.

Eisenberger, R., Stinglhamber, F.; Vandenberghe, C.; Sucharski, I. L. and Rhoades, L. (2002). Perceived supervisor support: Contributions to perceived organizational support and employee retention. Journal of Applied Psychology, 87(3), 565-573

Eisenberger, R., Fasolo, P. and Davis-Lamastro, V., (1990). Perceived Organizational support and employee diligence, commitment, and Innovation, Journal Of Applied Psychology, 75(1), 51-59.

Eisenberg, E. M., Monge, P.R. and Miller, K. I. (1987). Involvement in communication networks as a predictor of organizational commitment. HumanCommunication Research, 10(2), 179-201.

Greenberg J. (1994). Using socially fair treatment to promote acceptance of a work site smoking ban, Journal Of Applied Psychology, 79(2), 288-297

Gürbüz. S. ve Şahin. F. (2014). Sosyal bilimlerde araştırma yöntemleri Felsefe Yöntem Analiz, 1. Baskı, Ankara, Seçkin Yayıncıllk.

Gürbüz, R. (2012). Algllanan örgütsel destek ve örgütsel güvenin, örgütsel bağlllik ile ilişkisi, Yayımlanmamış Yüksek Lisans Tezi, Atatürk Üniversitesi, Sosyal Bilimler Enstitüsü, Erzurum.

Gürbüz. S. (2006). Örgütsel vatandaşlık davranışı ile duygusal bağlılık arasındaki ilişkilerin belirlenmesine yönelik bir araştırma. Ekonomik ve Sosyal Araştırmalar Dergisi, 3(2), 48-75

Heffernan, M. and Dundon, T. (2016). Cross-level effects of high-performance work systems (HPWS) and employee well-Being: The mediating effect of organisational justice, Human Resource Management Journal, 26(2), 211-231.

Hoş, C. ve Oksay, A. (2015). Hemşirelerde örgütsel bağlllık ile iş tatmini ilişkisi, Süleyman Demirel Üniversitesi İktisadi ve İdari Bilimler Fakültesi Dergisi, 20(4), 1-24.

İbicioğlu, H. (2000). Örgütsel bağlllıkta paradigmatik uyumun yeri. Dokuz Eylül Üniversitesi İktisadi ve İdari Bilimler Dergisi, 15(1), 13-22.

Kalaycı, Ş. (2008). SPSS uygulamalı çok değişkenli istatistik teknikleri. (3. Baskı). Ankara: Asil Yayın Dağıtım.

İmamoğlu, D. (2016). Cam tavan sendromu ile örgütsel bağlllık arasındaki ilişki: Kadın Çalışanlar Üzerine Bir Araştırma, Yüksek Lisans Tezi, Arel Üniversitesi Sosyal Bilimler Enstitüsü, İstanbul.

Kambu, A., Troena, E. A., Surachman, T. and Setiawan, M. (2012). Influence of leader member exchange, perceived organizational support, papua ethnic culture and organizational citizenship behavior toward employee performance of workers in papua provincial secretary office, IOSR Journal of Business and Management, 5(4), 31-38.

Kaplan, M. (2010). Otel işletmelerinde etiksel iklim ve örgütsel destek algılamalarının örgütsel bağlllık üzerindeki etkisi: Kapadokya örneği, Doktora Tezi, Selçuk Üniversitesi Fen Bilimleri Enstitüsü, Konya. 


\section{F. Keklik Okul 13/1 (2021) 464-480}

Karasandık, A. E. (2013). İş-aile çatışması ve duygusal bağlılık ilişkisinde algılanan örgütsel adaletin düzenleyici rolü, Yüksek Lisans Tezi, Nevşehir Üniversitesi Sosyal Bilimler Enstitüsü, Nevşehir.

Kenek, G. (2017). Etkileşimsel adalet, duygusal bağlllık ve alģlanan örgütsel destek ilişkisi: Bir kamu kurumunda araştırma, Yüksek Lisans Tezi, Gazi Üniversitesi Sosyal Bilimler Enstitüsü, Ankara.

Kim, K. Y., Eisenberger, R. and Baik, K. (2016). Perceived organizational support and affective organizational commitment: Moderating influence of perceived organizational competence, Journal of Organizational Behavior, 37(4), 558-583.

Kline, R. B. (2011). Principles and practice of structural equation modeling, (Fourth Edition). Guilford Publications, NewYork.

Köse, S. and Gönüllüoğlu, S. (2010). Örgütsel desteğin örgütsel bağlllık üzerindeki etkisini belirlemeye yönelik bir araştırma, Dumlupınar Üniversitesi Sosyal Bilimler Dergisi, 27, 1-8.

Kurtessis, J. N., Eisenberger, R., Ford, M. T., Buffardi, L. C., Stewart, K. A. and Adis, C. S. (2017). Perceived organizational support: A meta-analytic evaluation of organizational support theory, Journal of Management, 43(6), 1854-1884.

Marique, G., Stinglhamber, F., Desmette, D., Caesens, G. and De Zanet, F. (2012). The relationship between perceived organizational support and affective commitment: A social Identity perspective, Group \& Organization Management, 38(1), 68-100.

Mathieu, J. E. and Zajac, D.M. (1990). A review and meta-analysis of the antecedents, correlates, and consequens of organizational commitment, Psychological Bulletin, 108, 171-194.

Meyer, J. P. and Allen, N. J. (1997). Commitment in the workplace, theory, researchm and application. London:Sage Publications.

Meyer, J. P. and Allen, N.J. (1991). A three component conceptualization of organizational commitment, Human Resource Management Review, 1(1),61-89.

Mowday, R. T. (1998). Reflections on the study and relevance of organizational commitment. Human Resource Management Review, 8(4), 387-401.

Moorman, R. H., Blakely, G. L. and Niehoff, B. P. (1998). Does perceived organizational support mediate the relationship between procedural justice and organizational citizenship behaviour?, Academy of Management Journal, 41(3), 351-357.

Özakar, Ö., Ö. (2019). Alg̨lanan Örgütsel destek, psikolojik güçlendirme ve örgütsel bağlllık arasındaki ilişkiler: Banka çalı̧anları üzerine bir araştırma, Yüksek Lisans Tezi, Marmara Üniversitesi Sosyal Bilimler Enstitüsü, İstanbul.

Özdevecioğlu, M. (2003). Algılanan örgütsel destek ile örgütsel bağlllık arasındaki ilişkilerin belirlenmesine yönelik bir araştırma, Dokuz Eylül Üniversitesi İktisadi ve İdari Bilimler Fakültesi Dergisi, 18(2), 113130.

Porter, L.W., Richard, M. S. and Boulian, P. V. (1973). Organizational commitment, job satisfaction and turnover among psychiatric technicians, Journal of Applied Psychology, 59(5), 603-609.

Rhoades, L., Eisenberger, R. and Armeli, S. (2001). Affective commitment to the organization: The contribution of perceived organizational support, Journal of Applied Psychology, 86(5), 825-836.

Robbins. S.P., and Judge, T. A. (2013). Organizational behavior, 14.Basımdan Çeviri (Çev. İnci Erdem), Ankara: Nobel Yayın Dağıtım.

Sherwani, K. H. (2019). The Effect of Perceived Organizational support on employee's organizational commitment and employee behavior: The case of a construction company in Erbil City, Kurdistan Region, International Journal of Innovative Technology and Exploring Engineering, 8(953), 1270-1275.

Silbert, L.T. (2005). The effect of tangible rewards on perceived organizational support, Unpublished Master Thesis, Management Sciences, University of Waterloo, Canada. 


\section{F. Keklik Okul 13/1 (2021) 464-480}

Shore, L.M. and Tetrick, L.E. (1991). A construct validity study of the survey of perceived organizational support, Journal Of Applied Psychology, 76, 637-643

Shore, L. M. and Wayne, S. J. (1993). Commitment and employee behavior: Comparison of affective commitment and continuance commitment with perceived organizational support, Journal of Applied Psychology, 78(5), 774-780.

Takeuchi, R., Wang, M., Marinova, S. V. and Yao X., (2009). Role of domain-specific facets of Perceived organizational support during expatriation and implications for performance, Organization science, 20(3), 621-634.

Tamer, İ. and Bozayküt Bük, T. (2020). Algılanan örgütsel destek ve örgütsel bağlllık üzerine kavramsal bir inceleme, Avrasya Sosyal ve Ekonomi Araştırmaları Dergisi (ASEAD), 7(2), 139-147.

Tutar, H. (2007). Erzurum'da devlet ve özel hastanelerde çalışan sağlık personelinin işlem adaleti, iş tatmini ve duygusal bağlılık durumlarının incelenmesi, Süleyman Demirel Üniversitesi İktisadi ve İdari Bilimler Fakültesi, 12(3), 97-120.

Türkiye Bankalar Birliği (2020). İllere ve Bölgelere göre Banka Çalışan Sayısı İstatistikleri, https://www.tbb.org.tr/tr/bankacilik/banka-ve-sektor-bilgileri/verisor-gulamasistemi/illere-vebolgelere-gore-bilgiler/73 (Erişim Tarihi: 28. 10. 2019)

Üren, S. G. and Çorbacıŏglu S. (2012). Alg1lanan örgütsel desteğin örgütsel bağlllığa etkisi: İmalat sektöründe faaliyet gösteren bir işletme örneği, Gazi Üniversitesi İktisadi ve İdari Bilimler Fakültesi Dergisi 14(1), 29-52.

Wiener, Y. (1982). Commitment in organization a normative view, Academy of Management Review, 7(3), 418-428.

https://www.tbb.org.tr/tr/bankacilik/banka-ve-sektor-bilgileri/veri-sorgulama-sistemi/illere-ve-bolgeleregore-bilgiler/73, (Erişim Tarihi: 27.10.2020). 